\title{
CAMINHOS IDENTITÁRIOS: IMIGRANTES PORTUGUESES EM PERNAMBUCO*
}

\section{Contato \\ Rua da Vilarinha, 435 \\ 4100-514 - Porto - Portugal \\ wilzabetania@hotmail.com}

\section{-Wilza Betania dos Santos*}

Faculdade de Letras da Universidade do Porto Porto - Portugal

\section{Resumo}

A comunidade portuguesa em Pernambuco vivenciou uma nova fase de sua história a partir da criação do Gabinete Português de Leitura (GPL-PE) em 3 de novembro de 1850. O GPL-PE foi a primeira associação que formalizou os laços de pertencimento da comunidade portuguesa. A partir dele, outras instituições portuguesas foram constituídas. Foi em torno desse gabinete que se viu primeiramente surgir as discussões sobre a identidade do imigrante português. Este artigo objetiva compreender como os discursos sobre a identidade do imigrante português em Pernambuco foram (re)construídos e quais os caminhos percorridos por essa comunidade para (re)significar a imagem de colonizador-explorador para a de imigrante-construtor da nova nação brasileira. Analisando-se as variações dos discursos produzidos pelo próprio português no processo que (re) significaram sua identidade em Pernambuco entre 1850 e 1921.

\section{Palavras-chave}

Imigrante português - Identidades - Gabinete Português de Leitura - Tricentenário Camoniano - Pernambuco.

" Este artigo toma como base a dissertação de mestrado da autora que foi apresentada à Faculdade de Letras da Universidade do Porto (2013), com revisões que resultam da pesquisa de doutoramento em andamento, sob a orientação do professor doutor Jorge Fernandes Alves.

** Doutoranda em História, Faculdade de Letras da Universidade do Porto - Flup. Já atuou como professora e coordenadora da rede pública do estado de Pernambuco. Atualmente é investigadora no Centro de Estudos da População, Economia e Sociedade - Cepese, Porto, Portugal. Interessa-se por temas relacionados a identidades, nacionalismo e imigração. 


\title{
IDENTITY PATHS: THE PORTUGUESE READING ROOM
}

\section{DWilza Betania dos Santos}

Faculdade de Letras da Universidade do Porto Porto - Portugal

\begin{abstract}
The GPL-PE was the first association that formalized the ties of belonging of the Portuguese community. From GPL-PE other Portuguese institutions were formed. It was around this Room that for the first time discussions emerged about the identity of the Portuguese immigrant. This article aims to understand how the discourses on the identity of the Portuguese immigrant in Pernambuco was reconstructed and which were the paths taken by this community to (re)signify the image of colonizer-explorer to immigrant-constructor of the new Brazilian nation. In line with this approach, the constantly changing views produced by the Portuguese in the process of (re) construction of the discourses that (re) signified their identity in Pernambuco, between the years of 1850 and 1921, were analyzed.
\end{abstract}

\section{Keywords}

Portuguese immigrant - Identities - Portuguese Reading Room - Camonian Tercentenary - Pernambuco. 


\section{Introdução}

A identidade do imigrante português foi alvo de discussões diferenciadas das demais etnias que se estabeleceram no Brasil, pois o povo português permaneceu com uma imagem atrelada ao passado colonial. A sua identidade era definida através do binômio "colonizador-explorador" das riquezas nacionais e, para se deslocar desta imagem, os lusitanos representados neste artigo pelo Gabinete Português de Leitura de Pernambuco (GPL-PE) buscaram (re)construir uma outra imagem, a qual se baseou no binômio "imigrante-construtor"1 para o "progresso e civilização" da nação brasileira.

Na verdade, até 1822, apesar dos movimentos sociais que ocorriam em todo Brasil, a estadia dos portugueses e sua "imposição" era mais confortável. Porém, com a proclamação da independência uma nova realidade se estabeleceu e, não raras vezes, ocorreram movimentos que expressaram a contestação da identidade dos imigrantes portugueses radicados em Pernambuco. ${ }^{2}$

Conforme alude Marcus Carvalho, ${ }^{3}$ o ápice do antilusitanismo aconteceu tardiamente em Pernambuco: no Movimento Praieiro (1844-1849),

\footnotetext{
Por construtor entenda-se contribuidor.

2 De uma forma geral, o aparecimento do xenofobismo contra o luso tem temporalidade precisa, estando sempre inserido num contexto permeado de interesses políticos e sociais bem definidos. O historiador Evaldo Cabral de Mello subdivide os movimentos nativistas em três fases distintas: nativismo nobilárquico - inicia-se em 1650, quando da restauração contra o domínio holandês até a repressão dos nobres envolvidos na guerra dos mascates (1715); nativismo de transação - é aquele em que os nobres e mascates se unem em torno do mesmo topoi da restauração pernambucana; e nativismo radical - posterior a Conspiração dos Suassunas (1801). Esse se fez presente, principalmente, nos movimentos da década de 18401850. Os movimentos sociais mais destacados são a Revolução de 1817 (que teve o episódio conhecido como A Pedrosada), a Confederação do Equador em 1824 e a Insurreição Praieira em 1844-1849. Entretanto, em alguns outros como a Setembrizada (1831) e a Novembrada (1831), esteve presente a aversão ao imigrante português. Cf. ANDRADE, Manoel Correia de. Movimentos nativistas em Pernambuco: Setembrizada e Novembrada. Recife: UFPE, 1998. Além de outros dois movimentos poucos citados, e que demonstram a permanência do antilusitanismo: A Patriotada, ocorrida em Goiana em 1872, (conforme alega Cavalcanti, foi o resultado das "gaiatices" de Eça de Queiroz e Ramalho Ortigão contra d. Pedro II. Cf. CAVALCANTI, Paulo. Eça de Queiroz: agitador no Brasil. Recife: Editora Guararapes, 1983); e um outro evento ocorrido em Recife em 8 e 9 de abril de 1831), definido por Cavalcanti (1980) como um mata-marinheiro; Cf. CAVALCANTI, Paulo. O caso eu conto como o caso foi: da Coluna Prestes à queda de Arraes: memórias. Recife: Editora Guararapes, 1980; FERRAZ, Luiz Paulo Pontes. "Deus te leve a Pernambuco": antilusitanismo, legislação e estatística na história da imigração portuguesa para Pernambuco (1945 - 1964). Dissertação, UFPE, 2014.

3 CARVALHO, Marcus Joaquim Maciel de. O antilusitanismo e a questão social em Pernambuco, 1822-1848. In. PEREIRA, Miriam Halpern (org.). Colóquio Internacional sobre Emigração e Imigração em Portugal (SÉC. XIX E XX). Actas. Lisboa, Portugal: Editora Fragmentos, 1993, p. 145-162.
} 
quando já não existia perigo algum de recolonização do Brasil. O nativismo renasceu na província pernambucana como uma estratégia dos liberais em reunir a população urbana durante as eleições contra os conservadores, e rapidamente se materializou nos mata-marinheiros ${ }^{4}$ da década de 1840 . As motivações para a adesão aos mata-marinheiros não estavam restritas às disputas entre liberais e conservadores, pois a carestia e o desemprego na cidade de Recife, causados pela interrupção das reformas urbanas realizadas no governo do barão da Boa Vista (1837-1844) e pela crise algodoeira que levou à diminuição do movimento nas prensas e armazéns do Recife, também impulsionaram muitos a aderirem aos motins antilusitanos. Além disso, a grande seca entre os anos de 1844 e 1848 contribuiu para o aumento da migração do interior para a cidade do Recife, aumentando assim o quantitativo de desempregados e, consequentemente, a insatisfação contra os estrangeiros que ocupavam os postos de trabalhos disponíveis. ${ }^{5}$ No Movimento Praieiro ocorreram várias manifestações de rua (cerca de nove) cujo alvo eram os portugueses: os manifestantes saquearam lojas e exigiram a nacionalização do comércio a retalho. ${ }^{6}$

Mas as manifestações antilusitanas não findaram com o Movimento Praieiro, pois a imprensa continuou a propalar o lusofobismo. Em 1852, por exemplo, foram recopilados num livreto vários poemas de cunho antilusitano que circularam nos jornais e periódicos nativistas. ${ }^{7}$ Os poemas apresentavam o Brasil em alguns momentos como pátria, noutros como nação, e toda exaltação da pátria/nação brasileira contrapunha-se aos portugueses, os quais eram estigmatizados por termos pejorativos tais como "tyranos", "la-

\footnotetext{
${ }^{4}$ Os mascates portugueses eram chamados de marinheiros. Dessa forma, os mata-marinheiros eram agressões dirigidas aos portugueses ligados ao comércio, ou todos aqueles considerados nocivos pelos nativistas. Cf. FREYRE, Gilberto. Sobrados e mucambos. Rio de Janeiro: Livraria José Olímpio Editora S.A., 1977, p. 34.

Ibidem.

6 CÂMARA, Bruno Augusto Dornelas. Trabalho livre no Brasil imperial: o caso dos caixeiros de comércio na época da Insurreição Praieira. Dissertação de mestrado, CFCH, UFPE, 2005.

7 VIANNA, Luiz Pereira. Colecção de poesias patrióticas liberais brasileiras recopiladas dos jornaes desde o anno de 1826 até $1851, \mathrm{n}^{\circ} 3,1851 / \mathrm{n}^{\circ} 4$ e $\mathrm{n}^{\mathrm{o}}$ 6/1852. Rosas salienta que a situação do antilusitanismo no ano de 1866 ainda era forte ao ponto de a imprensa portuguesa se preocupar com a "segurança de vida e propriedade dos súditos portugueses residentes nessa província [Pernambuco]". Diário de Pernambuco, 11/09/1866. ROSAS, Suzana Cavani. Cidadania, trabalho, voto e antilusitanismo no Recife em 1860: os meetings no bairro popular de São José. In: XXV SIMPÓSIO NACIONAL DE HISTÓRIA. Anais. Fortaleza, 2009, p. 3.
} 
drões", "tosta cruel", "tigre insano", "monstro estrangeiro". Jeffrey Lesser, ${ }^{8}$ em importante estudo sobre a negociação da identidade nacional, chama a atenção para o fato de que o preconceito e os estereótipos que derivam das tensões sociais foram algumas das maneiras pelas quais a identidade do imigrante foi contestada. Nesse caso, os discursos antilusitanos funcionaram também como uma forma de contestação dos pernambucanos aos portugueses.

É dentro desse contexto de lusofobia que o presente artigo analisa como a comunidade portuguesa de Pernambuco se organizou frente às contestações de sua identidade no âmbito das associações, dentre as quais o Gabinete Português de Leitura de Pernambuco (GPL-PE), criado a 3 de novembro de 1850. Esta associação foi a que teve melhor desempenho no processo da (re) significação da imagem do imigrante português em Pernambuco. Em torno dela surgiram várias discussões sobre a identidade do imigrante português, inspiradas num passado que era interpretado de forma diferente pelos portugueses e pelos nativistas. Os primeiros evidenciavam as contribuições dos cidadãos portugueses aos brasileiros, esquadrinhando no passado colonial a base para a (re)construção do discurso identitário e a (re)significação da imagem do colono. Já os nativistas interpretavam esse mesmo passado numa perspectiva negativa, assumindo uma posição que reforçava a ideia de serem os lusos os exploradores da riqueza nacional.

Entre as várias interpretações surgiram novas identidades e, entre essas, nos interessa observar aquela que os próprios portugueses (re)construíram acerca de si mesmos. Para esse exame consideramos a perspectiva do outro, ou seja, a dos portugueses, a qual se fez baseada nas contraposições de pertencimento/distância, identidade/diferença, universalidade/particularidade. Essa leitura é importante porque desvincula o binômio português/ colonizador e contribui para o entendimento da presença dos portugueses em Pernambuco enquanto grupo de imigrantes que possuía identidade própria. Saliente-se, no entanto, que nesse caminho várias identidades se apresentaram, dentre as quais aquela que procurou defender que o português era elemento útil à "civilização" da nova nação independente.

Seguindo esse percurso de análise, este artigo se propõe a compreender as variações discursivas produzidas pelos integrantes do GPL-PE no processo da (re)significação da identidade do imigrante português radicado em

\footnotetext{
8 LESSER, Jeffrey. A negociação da identidade nacional: imigrantes, minorias e a luta pela etnicidade no Brasil. São Paulo: Unesp, 2001, p. 23.

9 DIELH,Astor Antônio.Cultura historiográfica:memória, identidadeerepresentação.Bauru, SP:Edusc, 2002, p.55.
} 
Pernambuco. Para isso, elegeram-se alguns momentos da história desta instituição considerados relevantes para o seu entendimento: entre as décadas de 1850-1860, busca-se compreender as variações dos discursos em torno da definição da identidade do imigrante português e a percepção dos nativistas na delimitação das fronteiras estabelecidas pelos representantes do Gabinete Português; a partir da década de 1870, entrou em cena a "preocupação" com a formação étnica da nação brasileira e, nessa discussão, o elemento português era apresentado, por alguns intelectuais, como um referencial positivo para o desenvolvimento da nação brasileira; a partir de 1880, com a comemoração do tricentenário camoniano, novos elementos foram inseridos na representação da comunidade portuguesa em Pernambuco, culminando com a construção do atual prédio do gabinete. É pautado nessa lógica que se analisou as variações dos discursos produzidos pelo próprio português no processo de (re)construção dos discursos que (re)significaram sua identidade em Pernambuco, entre os anos de 1850 e 1921. Apesar de longa, a delimitação temporal enfatiza os elementos em que se torna possível a identificação de alguns dos momentos em que os discursos do "ser português" ganharam novos sentidos. Dessa forma, a ênfase deste artigo é delimitada pela ocorrência dos momentos acima identificados.

\section{O Gabinete Português de Leitura e a sociedade pernambucana: delimitando as fronteiras identitárias}

O português João Vicente Martins (1808-1854), natural de Lisboa, era médico-cirurgião formado na Escola de Cirurgia de Lisboa. Em 1837, chegou ao Brasil e, até 1840, trabalhou em alguns hospitais no Rio de Janeiro. Em 1843, convertido à homeopatia, perseguiu os ideais de defesa da medicina homeopática e atribuiu a si mesmo a missão de levar a homeopatia ao norte do Brasil. Foi em "missão" pela causa homeopática que esteve em Pernambuco em 1850 onde, a convite, participou da criação do GPL-PE, sendo por isso o sócio fundador do mesmo.

Martins narrou todo o processo de criação do GPL-PE no periódico $O$ Médico do Povo, ${ }^{10}$ que circulou no Rio de Janeiro, Bahia e em Pernambuco, e relatou as dificuldades que teve para convencer alguns de seus patrícios que não se interessaram, naquele momento, em contribuir para a criação da instituição.

\footnotetext{
${ }^{10}$ Periódico criado por João Vicente Martins (1810-1854) e Sabino Olegário Ludgero Pinho (1820-1869).
} 
Mas, apesar da resistência de alguns portugueses, foi possível, com a ajuda de outros tantos, tornar real a criação do GPL-PE em 3 de novembro de 1850.

(...) Honra aos portugueses em Pernambuco pela unidade de pensamento e de vontade que os liga, sempre que lhes oferece ocasião de mostrar-se dignos da nação briosa a que pertencem, e esta generosa nação irmã sua, que lhes dá franca hospitalidade em troco de hospitalidade, também tão franca e tão generosa, que em Portugal recebem os filhos do Brasil. Possa a instituição do Gabinete Português de Leitura em Pernambuco ser uma demonstração bem clara dos sentimentos de fraternal amizade que unem os portugueses com os brasileiros, que de seus bens adquiridos á custa de tantas fadigas façam ricos patrimônios a seus filhos que aqui tenham, brasileiros, e nesta hospitaleira, que lhe de seus filhos e de suas esposas e de seus irmãos, estabeleçam e mantenham à custa de seus cabedais, muitas instituições como este Gabinete, pacíficas, morigeradoras e outras caridades (......" (Grifos meus)

Ao refletir sobre os discursos antiportugueses é possível compreender os pormenores da fala de João Vicente Martins na apresentação do GPL-PE aos pernambucanos. Martins abandonou os percalços com que se deparou ao buscar a ajuda de alguns portugueses residentes em Pernambuco, e considerou apenas o seu desejo e de uns poucos portugueses de ver nascer a instituição. Ponderava assim os aspectos positivos da comunidade portuguesa em seu discurso, apresentando a instituição como uma demonstração da união dos portugueses residentes na província pernambucana e também a expressão do respeito para com a nação que os havia gerado, ou seja, Portugal. O discurso de fraternidade utilizado na apresentação do GPL-PE a sociedade pernambucana enfatizava a união dos portugueses e brasileiros, numa expressa reação aos discursos radicais que solicitavam a quebra do monopólio português no comércio pernambucano, bem como atacava a ideia da presença “desagradável e maléfica” dos mesmos em Pernambuco. A "tática" de defesa discursiva não se fez sob a égide da acusação e justificativa, mas sob a retomada das ações positivas de seus compatriotas para com os pernambucanos. Ao dizer que se congratulava naquele momento com os senhores "Pernambucanos porque recebiam da associação de portugueses, tão nobre em seus fins, mais uma certeza que não desperdiçavam a sua hospitalidade com estrangeiros ingratos, que só queiram desfrutar o país sem

\footnotetext{
${ }^{11}$ MARTINS, João Vicente. Diário de Pernambuco, 12 /11/1850, p. 1.
} 
plantar nele árvore nenhuma que dê bons frutos",12 Martins externou três questões de suma importância para sua comunidade.

A primeira dizia respeito à apresentação da criação de uma instituição com fins nobres, explicitamente "civilizatórios". E assim sendo, o embasamento do discurso antilusitano caía por terra; a segunda é que os pernambucanos não estavam desperdiçando sua hospitalidade com "estrangeiros ingratos"; e por fim, Martins fez questão de associar o Gabinete Português de Leitura a uma "árvore frutífera" e útil à sociedade pernambucana. Atacava-se nesse discurso as acusações sofridas pela comunidade portuguesa, em que o português era o avarento e explorador das riquezas nacionais, e sobressaíam-se os lusos como povo civilizado, nobre, grato e útil aos pernambucanos. Nesse sentido, o gabinete foi apresentado como o órgão pacificador e era a prova cabal da boa intenção dos lusitanos em terras pernambucanas. A ingratidão apregoada pelos que nutriam a xenofobia se esvaía frente a esta instituição.

No discurso de João Vicente Martins, que denominamos aqui como "introdutório" à discussão que pretendia a (re)construção de uma identidade portuguesa em Pernambuco, ele primou pela negociação identitária e ratificou todas as contribuições da comunidade portuguesa aos pernambucanos. Martins evitou o conflito e o embate contra o posicionamento dos nativistas.

Ao destacar que a instituição era "uma demonstração bem clara dos sentimentos de fraternal amizade que unem os portugueses com os brasileiros",13 ele fez questão de enfatizar que estes portugueses possuíam bens que foram adquiridos "à custa de tantas fadigas", ${ }^{14}$ além de ressaltar que a prosperidade dos comerciantes portugueses era o fruto de seu empenho. Saliente-se, no entanto, que apesar da alegação da fraternidade que unia as duas nações, Martins colocou os portugueses na categoria de estrangeiros eles eram unidos pela fraternal amizade oriunda da pátria-mãe que também havia "concebido" o Brasil, mas eram diferentes: eram estrangeiros a viver numa nação irmã, concebida por eles mesmos.

A conjuntura vivida pelos portugueses foi contemplada em todos os aspectos no discurso de fundação do GPL-PE. Ao expressar a identidade coletiva do seu povo, Martins demonstrava preocupação com a orientação de sua fala, e esta articulação serviu como tese para a negociação identitária, pois, através da alocução da irmandade, retomava as narrativas do passado e en-

\footnotetext{
12 Ibidem.

13 Ibidem.

${ }^{14}$ Ibidem.
} 
dossava a continuidade do grupo. Essa foi a principal estratégia na negociação identitária utilizada pelos integrantes da instituição no primeiro momento.

É perceptível nesse discurso que o uso das semelhanças ecoava também em diferenças. Em resposta às acusações que sofriam buscava-se a negociação. Às agressões respondia-se com a retórica da fraternidade. Eram todos, lusos e pernambucanos, filhos da "nação briosa", ou seja, de Portugal. No contexto da continuidade discursiva antilusitana, as diferenças eram de certa forma negadas. Entretanto, isso não significou a descaracterização do grupo; pelo contrário, implicou nas estratégias da negociação das fronteiras identitárias.

Ao afirmar que em torno do Gabinete Português de Leitura os portugueses demonstravam-se dignos da nação a que pertenciam, Martins fez uso da memória, do passado comum entre seus conterrâneos, para assim formalizar a associação portuguesa em Pernambuco. Fátima Araripe, ${ }^{15}$ ao analisar o papel da memória, diz que o ser humano, por estar situado em um ambiente que contém um volumoso mecanismo do passado, busca nesse mecanismo aquilo que melhor se adeque ao seu próprio fim. Dessa forma, a memória é utilizada "para se obter uma identidade e laços de pertencimentos com a comunidade onde se insere".16 Além disso, o enfoque no parentesco, de serem frutos da "Nação briosa", trazia à tona o saber histórico, evocandose a memória como suporte necessário à legitimação de tal assertiva.

Enquanto participantes de um grupo, homens e mulheres levam consigo um sentimento de pertença ao tempo, ao lugar e às pessoas que formam esse grupo. O GPL-PE foi uma instituição que adquiriu um significado coletivo para seus membros, apresentava-se como lugar imbuído de sentidos; um lugar que se pretendia identitário, relacional e histórico. ${ }^{17}$ O GPL-PE identificava os lusos como diferentes, pertencentes à comunidade de origem, porém isso não os impedia de que se relacionassem com os brasileiros. Era possível que estes transpassassem as fronteiras sem que com isso "perdessem" a sua identidade. Fredrik Barth expõe que "se um grupo conserva sua identidade quando os membros interagem com outros, isso implica critérios para determinar a pertença e meios para tornar manifestas a pertença e a exclusão".18

\footnotetext{
15 ARARIPE, Fátima Maria Alencar. Do patrimônio cultural e seus significados. Campinas: Transinformação [online], 2004.

${ }^{16}$ Ibidem, p. 114.

17 AUGÉ, Marc. Não lugares: Introdução a uma sociologia da supermodernidade. Campinas: Papirus, 1994.

${ }^{18}$ POUTGNAT, Philippe \& STREIFF-FENARTE, Jocyline. Teorias da etnicidade. Seguido de grupos étnicos e suas fronteiras de Fredrik Barth. São Paulo: Editora da Unesp, 1998, p. 195.
} 
Nessa perspectiva, o GPL-PE, ao ser criado, assumiu a característica de uma comunidade simbólica, sentida por seus integrantes como extensão de sua pátria, não no sentido territorial, mas simbólico. Contudo, a apresentação deste gabinete aos pernambucanos foi posteriormente refutada em um artigo publicado no periódico $O$ Século. $\mathrm{O}$ artigo reflete a percepção de uma parcela dos pernambucanos, os nativistas, no que se refere à criação da instituição. Por o artigo ser autoexplicativo, transcrevemo-lo quase em sua totalidade.

\section{O Gabinete Litterario Portuguez}

Quando por aqui se espalhou a noticia de que o Sr. João Vicente Martins tinha criado nesta província um gabinete litterario portuguez, pouco apreço demos a isso, entendendo que sendo poucos os portuguezes que sabem ler e escrever correctamente a sua língua, e que teem alguns conhecimentos, essa instituição tinha por fim fazê-los aprender alguma cousa e applicarem-se a leitura: realmente não atinamos com o fim, a que parece hoje dirigir-se essa associação; mas agora em vista de certos fatos, e melhor refletindo sobre o caso, cremos que esse gabinete traz machiavelismo, e compreende mais política, do que instrucção.

Quem é o Sr. João Vicente Martins para promover a criação de um gabinete litterario em Pernambuco, e onde sómente entrem portuguezes? É um senhor que tem alguma habilidade, que passa por cirurgião homeopatha, que é muito vivo; mas que não ta num caso de um litterato, que só almeja o saber, a instrução, e que sacrifica seus dias e sua fortuna neste empenho. Mas supponha-se que Sr. João Vicente Martins é uma grande capacidade, o que só por hypothese adimittimos, e que ama a sciencia, e por isso a applicação aos estudos, e gosta de vê-la progredir, ainda assim achamos um pouco extraordinário que andando por tanta parte do Brasil, só se lembrase da criação de um gabinete litterario em Pernambuco, e na quadra atual, onde é mister muito tino e circumspecção em nossas acções para não nos fazermos supeitos de pertencer á esta ou aquella política, e de promovermos a queda ou sustentação e engrandecimento deste ou daquele partido. E porque este gabinete havia ser só de portugueses? Conhecemos nessa cidade e mesmo pela província alguns portuguezes muito poucos, que são homens de lettras; mas a mór parte são ignorantissimos e nenhum interesse de instrucção os poderia levar á criação desse gabinete, porquanto só cuidam do commercio, que sabem, que se instituio o gabinete litterario? Não, o fim é meramente político, ao menos assim parece a muita gente, e como era precisa em Pernambuco uma sociedade de portugueses, que executasse os planos da rua da Quitanda ${ }^{19}$ do Rio,

\footnotetext{
${ }^{19}$ A rua da Quitanda, a que se refere o artigo, era o endereço do Gabinete Português de Leitura no Rio de Janeiro. Essa relação, de que a criação do gabinete em Pernambuco era oriunda do Rio de Janeiro, não é improcedente, pois fez parte do discurso do fundador daquela instituição publicado no Diário de Pernambuco de 12 de novembro de 1850: "Sob o auspício da divina providência! Está fundado em Pernambuco um Gabinete Português de Leitura, conforme o plano e estatutos do Gabinete Português de Leitura do Rio de Janeiro" (grifos meus).
} 
e as ordens do Sr. Clemente Pereira ${ }^{20}$, eis o gabinete litterario criado aqui no Recife, a sociedade por conseqüência instalada, e tudo a caminho. (...)

Não tendo, pois, nada o gabinete litterario com a homeopathia, está claro que não é senão o amor de nosso paiz que nos faz apresentar estas considerações sobre a criação do tal gabinete, e para a qual há tanto empenho. Andão emissários pelo matto procurando portuguezes para o gabinete: o que é isto Sr. João Vicente? Que zelo, que desejo ardente de metter os pobres marinheiros, que vivem lá pelos engenhos e fazendas de algodão, no gabinete litterario? Sr. João Vicente, este seu gabinete litterario traz água no bico ! (...);

Estamos todos em uma situação anormal, a sociedade brasileira, e principalmente a pernambucana acha-se deslocada, e em estado de fermentação pelos ódios dos partidos, pelas perseguições e barbáries, que se ha feito aos opposicionistas, que mal podem fallar e escrever, mas sem direito de vida e propriedade, sem garantia alguma, etc.: ora, este estado não póde durar, hade acabar por força, porque a violência é um estado extranatural: para que pois os portugueses se querem expôr e arriscar, concorrendo agora deste ou daquele modo para continuação desta compressão, que esmaga os brasileiros? Para que se metter em política no Brasil, uma terra que não é delles, que não os gosta, e onde eles podião viver bem, tratando só de seus interesses? Há em Portugal algum brasileiro, que se intrometta na política da rainha, ou do povo? Fizemos lá algum gabinete litterario? Influímos lá de modo algum para os Cabraes venção ou não venção as eleições? Não, porque rasão pois os Srs. Portugueses lá no Brasil de metter-se a políticos, e bolirem com o que não lhes pertence?

Recuem enquanto é tempo; não fiem em ninguém, nem mesmo nos guabirus, porque quando se vivem perdidos, que lhe há de pagar o pato hão de ser os portuguezes. Senhores, vivei comnosco, sem trahir-nos, sede sinceros, não leveis a população do Brasil a praticar um excesso. O conselho é prudente.

Do Echo Pernambucano ${ }^{21}$ (grifos meus)

$\mathrm{O}$ artigo demonstra que estes nativistas perceberam a importância de tal gabinete de leitura para os portugueses. A maneira como o discurso foi articulado leva-nos a deduzir que tal percepção foi uma das formas de resistência à organização das fronteiras que demarcavam o lugar da comunidade portuguesa em Pernambuco. A concepção dessa fronteira identitária, por estar inserida numa conjuntura impregnada pelo sentimento antilusitano, se revela e é revelada nas/pelas convulsões da sociedade vigente.

\footnotetext{
${ }^{20}$ José Clemente Pereira, português de Trancoso, vivia no Rio de Janeiro e ali ocupava elevadas funções no governo à época de d. João VI e de d. Pedro I. Foi defensor da centralização no governo de d. Pedro II e também provedor vitalício da Santa Casa da Misericórdia.

${ }^{21}$ O Século, s. p., Recife, 1851.
} 
Assim, o discurso dita qual o lugar do estrangeiro (nesse caso o português) e o lugar do nativista na sociedade pernambucana. Violar tais limites significava traição e isso dava respaldo a toda e qualquer reação dos pernambucanos.

Outro aspecto do artigo é que, ao contextualizar o surgimento do GPL-PE, ele concebeu o mesmo como um subterfúgio para as discussões políticas, as quais cabiam somente aos nativistas. Por fim, justificou-se a "preocupação" com a criação/atuação da instituição, alegando-se que o cuidado com a mesma se fazia necessário, e tal cuidado era uma prova de amor ao Brasil, ou seja, o contraponto do amor à pátria era a permanente vigilância das ações dos portugueses residentes em Pernambuco. Assim, o zelo pelas questões de cunho nacional se tornava indissociável da repulsa aos portugueses.

Os discursos em torno da criação deste gabinete de leitura expressaram tanto os caminhos percorridos pelos portugueses para se inserir na sociedade de acolhimento - sem com isso perder sua identidade-como a rejeição da sociedade de acolhimento a esses portugueses, considerados estrangeiros "nocivos".

Partiu-se do pressuposto de que os portugueses já possuíam uma identidade que foi construída em consonância com o processo colonizador e, dessa forma, acredita-se que o Gabinete Português de Leitura foi uma instituição que se empenhou em (re)construir os discursos para (re)significar a identidade dos portugueses.

As palavras do comendador Miguel José Alves, chanceler de Portugal em Pernambuco à época da fundação do Gabinete Português de Leitura, servem como exemplo; disse ele que o objetivo da instituição era o de "Unir os portugueses residentes em Pernambuco, fomentar a sua unidade moral e congregando-os no culto à Pátria Portuguesa e ao amor ao Brasil".22

A ideia de "Pátria Portuguesa" traz à tona uma discussão de categoria étnica, sendo a etnia aqui usada para se referir às características culturais - língua, religião, costumes, tradições, sentimento de "lugar" - que são partilhadas por um povo. ${ }^{23}$ Roberto Cardoso de Oliveira ${ }^{24}$ diz que o termo etnicidade é aplicado, com valia, para a análise da interação de imigrantes em uma terra estrangeira. Mas, trabalhar com o termo da etnicidade atrelado aos portugueses que residiam no Brasil torna-se complexo exatamente pelo passado colonial comum, fato diferente em relação à situação dos outros

\footnotetext{
${ }^{22}$ AREIAS, Laura E NOGUEIRA, Lucila. Monografia do Gabinete Português de Leitura. Recife, 2000, p. 28.

${ }^{23}$ HALL, Stuart. Identidade cultural na pós-modernidade. Rio de Janeiro: DPE\&A, 2000, p. 62.

${ }^{24}$ OLIVEIRA, Roberto Cardoso. Caminhos da identidade: Ensaios sobre etnicidade e multiculturalismo. São Paulo: Editora Unesp, 2000.
} 
imigrantes que se estabeleceram também no Brasil no século XIX. Apesar da conflitualidade discursiva que destacava o português como uma figura negativa, não se pode negar que as semelhanças com a comunidade receptora eram notáveis: falava-se a mesma língua, seguia-se a mesma religião; ocorria um fluxo cultural entre a comunidade de acolhimento (pernambucanos) e a que se estabelecia (portugueses).

Geralmente é com base na diferença que um grupo mantém sua identidade, e esta, ao ser invocada, faz surgir as fronteiras. Para se compreender o significado do termo "fronteiras", a análise de Fredrik Barth é apropriada, pois ela diferencia a cultura da identidade afirmando que:

O que separa dois grupos étnico-culturais não é, em princípio, a diferença cultural; uma coletividade pode funcionar perfeitamente admitindo em seu seio uma pluralidade cultural. O que cria a separação é a "fronteira", é a vontade de se diferenciar e o uso de certos traços característicos como marcadores de sua identidade específica ${ }^{25}$ (grifo do autor).

É certo que as categorias étnicas consideram as diferenças culturais, afirma Barth. No entanto, "as características que devem ser levadas em conta não são a soma das diferenças 'objetivas', mas somente aquelas que os próprios atores consideram significantes". ${ }^{26}$ Essa definição é bastante adequada para entendermos o caso do imigrante português em Pernambuco. Através dela se compreende que a etnicidade construída pelos lusos era situacional, ou seja, se adequava ao contexto vigente. Os discursos produzidos pelos integrantes do GPL-PE eram expressivos dessa situação.

A fala de João Vicente Martins exposta anteriormente, por exemplo, aponta para uma negociação identitária. Martins retoma no passado comum o elo fomentado por este passado. Então, com base no tempo passado buscou negociar uma identidade portuguesa, a qual vinha sofrendo agressões através dos discursos antilusitanos propalados pela imprensa. Ao fazer uso da memória, Martins não somente engrandeceu a sua terra natal, mas também atrelou a grandeza daquela que ressoava no Brasil.

É importante registrar que, por outro lado, os brasileiros fizeram uso da memória para evocar a ideia de ser Portugal aquele que desde o passado colonial explorava o Brasil. Há um conflito nesse aspecto, e cada evocação ao passado visava apenas afirmar os interesses das partes envolvidas.

\footnotetext{
${ }^{25}$ Apud CUCHE, Denys. A noção de cultura nas ciências sociais. Bauru: Edusc, 1999, p. 200.

${ }^{26}$ POUTGNAT, Philippe \& STREIFF-FENARTE, Jocyline, op. cit., p. 194.
} 


\section{Instituições em torno das identidades}

As discussões pseudocientíficas sobre "raça" tornaram-se frequentes no Brasil a partir da década de 1870. Nesses debates, alguns cientistas, intelectuais e políticos ressaltavam a necessidade de aprimorar a "raça" brasileira. O deputado e intelectual alagoano Tavares Bastos (1839-1875), por exemplo, defendia que acabar com a escravidão e incentivar a emigração branca não eram uma questão de compaixão, mas um passo para o progresso e a civilização, pois o negro era a causa do atraso e trazia prejuízo aos avanços da nação brasileira. Bastos se pautava nas teorias raciais em voga naquele período. ${ }^{27}$ Por esse período, alguns intelectuais apontaram para as afinidades dos portugueses e sua importância para a formação de uma identidade brasileira civilizada. Concebiam a imigração em massa de portugueses como a mais vantajosa para "aprimorar a raça brasileira". A "vantagem" dos lusos foi alardeada na crise de esgotamento do escravismo e em momentos de maior afluência de italianos, alemães e poloneses. Intelectuais como Sílvio Romero teceram críticas ao sistema de colônias estabelecido no sul do país, atacando, principalmente, a concentração populacional germânica por formar colônias que não se misturavam, tendo em vista seus valores alegadamente "estranhos" à brasilidade. Contra este perigo, propunha-se o assentamento preferencial de portugueses nas mesmas regiões, com o intuito de valorizar a mão de obra branca no mercado de trabalho e, consequentemente, gerar o "branqueamento" da nação brasileira no pós-independência. Conforme salienta $S_{c h w a r c z}{ }^{28}$ as políticas de imigração buscaram reescrever e branquear a constituição da população brasileira. Nesse panorama, vários intelectuais

\footnotetext{
${ }^{27}$ O século XIX foi palco da divulgação das teorias do arianismo, a qual teve como principal divulgador o conde de Gobineau, que esteve no Brasil entre os anos de 1869-1870 e manteve amizade com o imperador brasileiro. Gobineau previa que, devido ao cruzamento das "raças", em menos de duzentos anos os habitantes brasileiros estariam fadados ao desaparecimento. Outro aporte teórico que fundamentou as ideias dos intelectuais que discutiram a formação da identidade nacional foi o darwinismo social, uma teoria da evolução social que se baseava na analogia com as ciências biológicas. Distorcendo as ideias de Darwin, alguns pensadores consideravam que a presença do negro era extremamente negativa ao ideal do progresso e da civilização. Outra forma de interpretação se baseou no evolucionismo social, o qual propunha a interpretação do desenvolvimento sociocultural do homem baseado no conceito de evolução. Nessa interpretação o ponto máximo do progresso humano era a cultura europeia ocidental, as demais culturas eram consideradas primitivas.

${ }^{28}$ SCHWARCZ, Lilia Moritz. O espetáculo das raças: cientista, instituições e questão racial no Brasil - 18701930. São Paulo: Companhia das Letras, 1993.
} 
brasileiros se empenharam em definir as características do que era ser um nacional. E para sê-lo era necessário ter nascido em território brasileiro, falar idioma português e seguir a religião católica.

Para compreender melhor esta temática recorreu-se ao Gabinete Português de Leitura do Rio de Janeiro (GPL-RJ), criado em 1837. Em sua formação, o GPL-PE esteve ligado ao GPL-RJ e adotou o seu estatuto ${ }^{29}$ como guia. O que se supõe com a realização deste estudo é que esta influência se estendeu por todo o século XIX, inclusive quando se trata dos discursos ligados à formação da identidade nacional e às teorias raciais. Geralmente, tais discursos, bem como os relatórios e outros documentos de ambas as instituições, eram enviados de uma para a outra. Em alguns momentos foi possível perceber que as trocas de experiências influenciaram nas decisões tomadas pelos sócios do gabinete de Pernambuco.

Um fato que se relaciona à formação da identidade nacional brasileira merece destaque: o convite feito pelo Gabinete Português de Leitura do Rio de Janeiro ao escritor Sílvio Romero, em 1890, para proferir uma conferência. O escritor não foi escolhido por acaso, pois era conhecida sua tendência à valorização do português como elemento positivo para a definição do "tipo ideal do brasileiro". Romero, apesar de considerar a mistura das três etnias (o índio, o branco e o negro) como formadora do brasileiro, foi partidário da teoria da assimilação para o branqueamento da "raça" final. Nessa perspectiva, a valorização dos europeus considerados assimiláveis passou a ser o ponto nevrálgico de sua tese. Romero considerou que, devido ao passado comum de portugueses e brasileiros, os lusos eram importantes no processo da assimilação e, por isso, recebeu o reconhecimento da comunidade portuguesa do Rio de Janeiro que era representada pelo Gabinete Português de Leitura daquela província.

A palestra proferida por Romero no gabinete do Rio de Janeiro - O Elemento português no Brasil -, baseava-se na tese da formação da nacionalidade brasileira e os riscos da inserção dos povos inassimiláveis em sua população e reafirmava a importância do elemento português na formação da população e na cultura nacional. Ele defendia o incentivo à emigração portuguesa para o Brasil e seu benefício para a composição da nação. Além disso, chamou a atenção para o perigo dos povos inassimiláveis, principalmente os alemães e italianos, os quais formavam colônias no sul do país e

${ }^{29}$ O Médico do Povo, 23/10/1850, p. 26-32. 
em São Paulo. Segundo Romero, isso ocorria por causa de um equívoco do Império e descaso da República. ${ }^{30}$ Exaltou ainda em seu discurso o fato de o povo português não buscar a distinção do brasileiro, e isso por se sentir componente da formação do Brasil, além de reafirmar a importância dos mesmos na base identitária da nação, pois os brasileiros herdaram deles a língua e a religião. Para Romero, tudo isso se traduzia na fraternidade entre ambas as nações. No contexto do moderno imperialismo, Romero avaliou que somente pela afirmação da formação luso-americana e o fortalecimento das relações econômicas e culturais com Portugal é que o Brasil perderia a vulnerabilidade a que ficaram restritos os continentes asiático e africano.

Ao analisar a conferência proferida por Romero, Tatiana Bastos considerou que o discurso proferido por ele foi uma das expressões do imaginário que se queria construir por intermédio da ação do Gabinete Português de Leitura do Rio de Janeiro naquele período. Alguns elementos contidos na fala do conferencista como a relação da origem brasileira ligada à colonização portuguesa, a utilização da mesma língua, a ideia da fraternidade e a valorização da imigração portuguesa eram questões de extrema importância para aquilo que os integrantes do Gabinete Português de Leitura do Rio de Janeiro se propunham a consolidar, bem como a grande parte da colônia de imigrantes portugueses na capital brasileira. Nesse cenário, diz a historiadora, a "valorização da cultura lusitana pelos integrantes do Gabinete Português [Rio de Janeiro] corresponde à tentativa de consolidar para a sociedade brasileira a ideia benéfica e positiva do imigrante português" ${ }^{31}$ Gilberto Freire igualmente valorizou a imigração portuguesa na construção da identidade nacional e também discursou no Gabinete Português de Leitura de Pernambuco em 1940.32

Um ano após a criação do Gabinete Português de Leitura do Rio de Janeiro, foi criado, em 21 de outubro de 1838, o Instituto Histórico e Geográfico Brasileiro (IHGB) na capital brasileira. Este instituto veio para produzir um saber oficial e construir uma história nacional que levasse o imenso império

\footnotetext{
${ }^{30}$ ROMERO, Sílvio. O Elemento português no Brasil. Conferência. Lisboa: Typ. da Companhia Nacional Editora, 1902 [1890]. Apud BASTOS, Tatiana Quintela de Azeredo. Gabinete Português de Leitura: construção de uma identidade portuguesa (1837-1893). Dissertação, UFRJ, 2007, p. 39. O livro de Romero está disponível em http://purl.pt/17312 (acesso em 26 de dezembro 2017).

${ }^{31}$ Ibidem, p. 36.

${ }^{32}$ A convite do governo português, Freire leu no Gabinete Português de Leitura de Pernambuco a conferência que foi publicada no Recife, em 1940, em edição particular: Uma cultura ameaçada: a luso-brasileira.
} 
a obter um passado comum que respaldasse a escrita de uma história do Brasil a ser divulgada pela revista da própria instituição.

No discurso da fundação do IHGB, o cônego Januário da Cunha Barbosa alegou que a história do Brasil deveria ser escrita não nos moldes provincianos, pois essa não era uma história de particulares, mas a história geral precisava ter "encadeados os seus acontecimentos com esclarecido critério, com dedução filosófica, e com luz pura da verdade". ${ }^{33}$ A meta era que o instituto congregasse o maior número possível de documentos para construir uma história geral e filosófica do Brasil. ${ }^{34}$

A Revista do IHGB defendia que a história nacional não poderia ser construída em oposição à metrópole, porém considerava ser necessária a construção de diferenciações e de fronteiras de uma identidade brasileira diferente da portuguesa. ${ }^{35} \mathrm{Um}$ dos participantes deste Instituto, o ministro do Império barão Homem de Mello, enfocou em um de seus estudos (1871) o lado benéfico da colonização portuguesa para a história da formação nacional, evidenciando a grandeza da origem brasileira. ${ }^{36}$

O posicionamento dos componentes do IHGB diferenciava-se do comportamento dos sócios do Instituto Arqueológico Histórico e Geográfico de Pernambuco (IAGP), ${ }^{37}$ instituição criada em 28 de janeiro de 1862. Apesar de ser uma das metas iniciais do IHGB a criação de sucursais, a criação do

\footnotetext{
33 Apud FERRÃO, Luiz Felipe Vieira. Instituto Arqueológico Geográfico Pernambucano: um tributo a memória regional (1848-1911). Dissertação, PPGH, UERJ, Recife, 2001, p. 22.

${ }^{34} \mathrm{O}$ IHGB dedicou-se a ideia de construir uma história nacional baseada num passado que orgulhasse a nação e a fizesse seguir em frente. Em 1847, Von Martius venceu o concurso que tinha o objetivo de escolher um plano para escrever a história do Brasil, com o artigo intitulado "Como se deve escrever a história do Brasil". O texto de Martius estabeleceu as bases da história científica da "nação" brasileira, a qual foi posteriormente executada por Varnhagen. Cf. KHALED JÚNIOR, Salah Hassan. Horizontes identitários: a construção da narrativa nacional brasileira pela historiografia do século XIX. Porto Alegre: EdiPUCRS, 2010; ODALIA, Nilo. As formas do mesmo: ensaios sobre o pensamento historiográfico de Varnhagen e Oliveira Vianna. São Paulo: Unesp, 1997; CEZAR, Temístocles. Como deveria ser escrita a história do Brasil no século XIX. Ensaio de história intelectual. In: PESAVENTO, Sandra Jatahy. História cultural: experiências de pesquisa. Porto Alegre: UFRGS, 2003; GUIMARÃES, Manoel Luiz Salgado. História e natureza em Von Martius: esquadrinhando o Brasil para construir a nação. História, Ciência e Saúde - Manguinhos, vol. 7, n. 2, Rio de Janeiro, 2000.

${ }^{35}$ BASTOS, Tatiana Quintela de Azeredo, op. cit., p. 29.

${ }^{36}$ Ibidem, p. 31.

${ }^{37}$ O IAGP quando fundado denominava-se Sociedade Arqueológica Pernambucana. Em 16 de agosto, ao ser aprovado o seu primeiro estatuto, teve o seu nome modificado para Instituto Arqueológico e Geográfico Pernambucano (IAGP). A partir de 10 de novembro de 1920, dia da inauguração da atual sede, passou a ser chamado Instituto Arqueológico, Histórico e Geográfico Pernambucano (IAHGP).
} 
IAGP não despertou nenhuma atenção do IHGB. Conforme alude Ferrão, o grêmio pernambucano não fez questão da proteção da associação do Rio de Janeiro; na realidade, se comportou como igual e solicitou reconhecimento sem pretender com isso se submeter aos ditames do IHGB. ${ }^{38}$

Contrariando a proposição estabelecida pelo IHGB de uma história geral, muitos dos sócios do IAGP defendiam o ponto de vista da abordagem de uma história provincial, pois a história centralizada não respeitava as singularidades das províncias. Outro aspecto que se contrapôs à perspectiva do instituto do Rio de Janeiro refere-se à participação dos portugueses na sua composição. Percebe-se que o IHGB, por adotar um discurso de exaltação à "raça" portuguesa, se aproximou do Gabinete Português de Leitura do Rio de Janeiro. Já em Pernambuco, ao contrário, o IAGP, em 1862, somente tinha como sócio um único português, José Soares de Azevedo, com formação no curso de Letras e que exercia o magistério no Liceu Pernambucano. Ferrão argumenta que dentre muitas explicações prováveis, a lusofobia acentuada na província pernambucana pode ter sido a causa dessa situação. Afinal, a biografia de alguns dos sócios do IAGP, como Muniz Tavares, mostrava que este, noutro tempo, defendera abertamente a expulsão dos portugueses da província pernambucana. ${ }^{39}$

Porém, na comemoração do décimo oitavo aniversário do Gabinete Português de Leitura de Pernambuco, em 1869, o IAGP não deixou de responder ao convite recebido do gabinete e enviou representante à festividade da instituição. O representante enviado foi o dr. Aprígio Justiniano da Silva Guimarães que, em discurso aos presentes na sessão comemorativa, disse:

Em tempos remotos da nossa nacionalidade que era então portugueza, vemos os nossos antepassados combatendo pela Liberdade e pela Cruz; e se venceram, foi que o consorcio das duas divindades não era desagradável ao Omnipotente.

Quando o Batavo audaz e astucioso pisou terras do Brasil, os nosso antepassados de Pernambuco reclamaram para logo a liberdade das suas crenças; e o conde Mauricio, vencendo escrúpulos e preconceitos de seus companheiros d'administração, cedeu às leis da justiça, obedeceu às exigências da lei natural da liberdade de consciência.

\footnotetext{
${ }^{38}$ FERRÃO, Luiz Felipe Vieira, op. cit., p. 24.

39 Ibidem, p. 32.
} 
(...) Com effeito, se a meu lado um homem respeita minha vida, a minha propriedade, à minha honra, se esse homem obedece como eu as leis instauradas para uma boa coexistência social - o que importa a mim, sob o ponto de vista social, que elle adore a Deus, d'este ou d'aquelle modo? ${ }^{40}$

O discurso pronunciado pelo representante do IAGP distanciou-se dos discursos dos demais representantes das outras instituições que participaram da festividade, pois todas elas se restringiram a exaltar a instituição e a pátria portuguesa, uma vez considerarem a data em efeito. O próprio orador salientou ao final de suas palavras: "Mas, Senhores, por que roubeivos tantos momentos, arrazoando assumpto que poderia parecer estranho à occasião?". ${ }^{41}$ Logo em seguida, justificou dizendo que partiu do IAGP com o intuito de trazer daquela instituição uma recordação da história da pátria, e essa era uma lembrança da luta dos antepassados durante a dominação holandesa "em defeza de sua consciência - Liberdade e Cruz!". ${ }^{2}$

Na ocasião da data comemorativa do GPL-PE, o orador se dirigiu ao monarca português e descreveu a instituição como uma associação patriótica, além de apresenta-la como uma demonstração do amor de seus súditos em terras pernambucanas. E como homenagem e demonstração da gratidão de todos os portugueses ao rei, libertou-se um escravo naquela ocasião. ${ }^{43}$

De uma forma geral, os discursos proferidos nesse período em torno do Gabinete Português de Leitura de Pernambuco fundamentaram-se na exaltação da nação portuguesa. As alocuções eram uniformes em glorificar a instituição, destacando sua contribuição à colônia portuguesa. A instituição aparecia consagrada como uma "árvore frondosa" que havia gerado frutos valiosos como: o Monte Pio Português de Beneficência e o Hospital Português do Recife. No sermão proferido naquela festividade, o pe. Leonardo João Grego ${ }^{44}$ fez questão de frisar o pioneirismo da instituição na "missão civilizadora" na província pernambucana, definindo-a como "o primeiro padrão de glória que enobrece a família portugueza no norte ao império" ${ }^{45}$

A partir da década de 1870, as discussões que valorizavam a presença do português para o fortalecimento da formação da nação brasileira ga-

\footnotetext{
${ }^{40}$ Fastos do Gabinete Portuguêz de Leitura em Pernambuco. 1970, p. 19-20.

${ }^{41}$ Ibidem, p. 28.

42 Ibidem, p. 29.

43 Ibidem, p. 58.

${ }^{44}$ Presbítero secular e cavaleiro da Ordem de Cristo.

45 Fastos do Gabinete..., op. cit., p. 120.
} 
nharam mais força nos discursos produzidos pelo Gabinete Português de Leitura. Na década de 1880, Camões ressurgiu como a expressão maior de Portugal e o símbolo da gente lusitana, tanto em sua terra natal quanto onde existissem representantes da colônia portuguesa.

\subsection{Camões: o herói de Portugal e símbolo do emigrante português}

A ideia de comemorar a morte de Camões foi sugerida por Joaquim de Vasconcelos, sócio da Sociedade de Geografia em Lisboa, em 17 de maio de 1879. Entretanto, somente em janeiro de 1880 foi que a mesma ganhou impulso, após a publicação de um artigo no jornal Comércio de Portugal pelo diretor da revista $O$ Positivismo, Teófilo Braga. Nesse artigo, Braga afirmava que o povo tinha de escolher "o gênio que é a syinthese do seu caracter nacional, aquelle que melhor exprimiu essas tendências, ou o que mais serviu a essa individualidade ethnica". ${ }^{46}$

Para Teófilo Braga, o poeta Camões era o mais perfeito emissário da nacionalidade portuguesa por ter cantado o descobrimento do caminho marítimo para o Oriente, fato histórico que mais contribuiu para o progresso humano. Ao mesmo tempo em que a epopeia camoniana se fez universal por seu tema, também se fez nacional pois sua poesia traduzia os feitos portugueses. A comemoração da morte do poeta, bem como a sua evocação, estava associada aos momentos mais graves de crise da nação. Por isso, para Teófilo Braga a leitura de Os lusíadas servia de acalento para aqueles que lastimavam a perda da independência nacional, alentando a sua recuperação em 1640. Braga ainda considerou que, assim como no passado, a comemoração do centenário significava uma "revivescência nacional". ${ }^{4}$

Mas somente três meses antes da data comemorativa, em 10 de junho de 1880, se tomou a iniciativa para a realização do tricentenário de Camões. A atitude foi encabeçada pelo secretário perpétuo da Sociedade de Geografia e jornalista do Comércio de Lisboa que convocou toda a imprensa e assumiu a responsabilidade da comemoração. A organização de tal comemoração foi

\footnotetext{
${ }^{46}$ BRAGA, Teófilo. O centenário de Camões em 1880. Comércio de Portugal, Lisboa, 8 de janeiro de 1880. Apud JOÃO, Maria Isabel. Memória e Império: comemorações em Portugal (1880-1960). Lisboa: Fundação Calouste Gulbenkian, 2002, p. 52.

${ }^{47}$ Ibidem, p. 52, 53.
} 
uma demonstração de ser Camões uma figura consensual na sociedade portuguesa, um célebre gênio e símbolo da nacionalidade. ${ }^{48}$

Um deputado português, em seu discurso de defesa da data comemorativa, expressou aquilo que todos os partidários da comemoração pensavam. Disse ele: "relembrar os mortos é estimular os vivos; recordar Os lusíadas é reviver a melhor ephoca da nacionalidade portugueza, e acordar um mundo onde Portugal foi senhor, foi grande, foi omnipotente". ${ }^{49}$ Nesse sentido, pensar Camões era fazer renascer o "velho espírito" que havia feito a "cavallaria patriótica redemptora, [que] civilisou a Africa, a Asia e a America". 50

Havia ainda aqueles que acreditavam que evocar Camões no centenário de sua morte despertaria a sociedade portuguesa para a necessidade de transformações. Tal comemoração, ao ter como objetivo manter vivas as memórias, retomou como exemplo a "época grandiosa" da história nacional. Sendo assim, reviver Camões era também acreditar num futuro melhor. ${ }^{51}$ Eduardo Lourenço, no livro Mitologia da saudade, faz algumas considerações sobre o grande mito que se tornou Camões para os portugueses.

A identificação de Portugal com Camões, por hora conjugada dos acontecimentos históricos e da revolução cultural romântica, é um caso único no quadro da cultura europeia. Durante todo o nosso século XIX há uma espécie de vaivém entre a leitura que fazemos do nosso destino coletivo e imagem de Camões. Ou, antes, do seu Livro, que se converterá ao mesmo tempo na estátua do Comendador da nossa cultura e seu anjo da guarda, em nosso juiz e nossa esperança de redenção. Para os portugueses, Camões não será apenas o maior dos poetas - era-o já, desde o século XVII, (...) - mas, o seu herói nacional. Apenas o estilo do nosso destino coletivo e a história do nosso imaginário podem explicar essa conversão do autor d'Os Lusíadas em símbolo de Portugal. É a esse título que, com maior naturalidade, Camões se torna objeto das nossas paixões nacionais, que são menos literárias ou culturais do que ideológicas, patrióticas, cívicas e por vezes partidárias. Se ainda hoje, um pouco por toda a parte, as associações de emigrantes portugueses se colocam sob a égide de Camões, isso se deve a esse incrível processo de mitificação e, pode mesmo dizer-se, de divinização do sentimento nacional que se dá no primeiro quartel do século XIX.52

\footnotetext{
48 Ibidem.

49 ARANHA, Brito. Diccionario bibliographico portuguez, 1888, p. 24. Apud JOÃO, Maria Isabel, op. cit., p. 54.

${ }^{50}$ Ibidem, p. 55.

51 JOÃO, Maria Isabel, op.cit., p. 58.

52 LOURENÇO, Eduardo. Mitologia da saudade: seguido de Portugal como destino. São Paulo: Companhia das Letras, 1999, p. 57.
} 
A definição de Camões como referencial e símbolo da nação portuguesa no século XIX também repercutiu no Brasil. Os gabinetes portugueses de leitura do Rio de Janeiro, de Pernambuco, do Maranhão e da Bahia aderiram às comemorações do tricentenário de Camões em 10 de junho de 1880. Nas palavras do relator da celebração do centenário de Camões no Rio de Janeiro, se não fora o gabinete de leitura tal comemoração não teria ocorrido com a pompa devida no Brasil. ${ }^{53}$

Em Pernambuco, conforme as narrativas da diretoria do gabinete, a repercussão da comemoração foi grande e o evento durou três dias. A propaganda sobre a festa foi divulgada no jornal Diário de Pernambuco. A primeira notícia difundida no Diário de Pernambuco foi em 4 de junho de 1880 sobre a divulgação da tiragem dos Sonetos de Camões, e quem se interessasse em obtê-lo deveria encomendá-lo. ${ }^{54}$ Conforme relatório da diretoria do gabinete, os Sonetos foram produzidos no Porto, uma tiragem de mil exemplares. ${ }^{55}$ No dia 5 de junho, a diretoria do Gabinete Português de Leitura publicou uma solicitação a todas as associações que tinham sede na cidade, bem como a todos os moradores a iluminarem as fachadas de seus prédios nas noites de 8, 9 e 10 de junho para os festejos a Camões, das 16 horas em diante. A diretoria pediu também aos donos de estabelecimentos comerciais que fechassem suas portas no dia 10 de junho, no mínimo a partir das 16 horas. ${ }^{56}$

Conforme relato de Paulo Cavalcanti, as ruas Larga do Rosário e Duque de Caxias também foram iluminadas e, nesta última, foi formado um arco e posto um coreto onde uma banda de música tocou até as últimas horas do dia 8. A propaganda do drama sobre Camões a ser apresentado no teatro Santa Isabel no dia 9 de junho também foi divulgada diariamente pela imprensa pernambucana. ${ }^{57}$

Na culminância da comemoração do terceiro centenário de Camões - no dia 10 de junho -, foram queimadas em frente ao edifício do Gabinete Português de Leitura e em outros pontos do Recife várias girândolas de foguetes. Além disso, um grande letreiro com o nome "Camões" aparecia na sede da Companhia de Iluminação a Gás, à rua do Imperador. Naquele dia, partiram duas bandas de músicas da porta do gabinete e do largo do Arsenal da Ma-

\footnotetext{
53 Terceiro centenário de Camões. Juízo da Imprensa do Rio de Janeiro acerca do relatório da diretoria do Gabinete Português de Leitura em 1880. Rio de Janeiro, 1880, p. 6.

54 Diário de Pernambuco, 4/06/1880, p. 6.

55 Relatório, 18/nov/1880 (página ilegível).

56 Ibidem, p. 4.

57 Ibidem, 6, 7, 8/jun/1880.
} 
rinha, as quais percorreram toda a cidade, concentrando-se na frente dos prédios do Diário de Pernambuco e do Jornal do Recife. Todos os navios mercantes brasileiros e portugueses que estavam aportados no porto do Recife se embandeiraram em sinal de gala. O comércio fechou logo ao entardecer e uma multidão se dirigiu para o bairro de Santo Antônio onde ocorriam as festividades com as bandas marciais que animavam a multidão. No teatro Santa Isabel celebrou-se o tricentenário de Camões e tamanha foi a concorrência que em poucos minutos não havia um lugar sequer. A lotação do teatro, que era de oitocentas a novecentas pessoas, ultrapassou três mil. A decoração interna do teatro ostentou no fundo do palco o retrato de Camões, sendo postos nos degraus do trono vários bustos em gesso de homens célebres nas ciências e nas letras. No dia 12 de junho, um grupo de jovens, ainda sob o efeito da comemoração, organizou um baile que, apesar da oposição de uns e outros, ocorreu nos salões do Clube Euterpe sob a aprovação da diretoria do clube.

Diversas autoridades foram convidadas para o evento, como os cônsules de Portugal, Espanha, Peru e Uruguai, além dos representantes da Câmara Municipal, do Instituto Arqueológico e Geográfico Pernambucano, do Montepio Português, da Santa Casa da Misericórdia, do Instituto Literário Olindense, da Sociedade Recreativa Juventude, do Clube Carlos Gomes, do Clube Abolicionista, da Irmandade do Bom Jesus dos Passos, do Hospital Português. Além destes, foram também convidados os representantes da imprensa: Jornal do Recife, Diário de Pernambuco, Ideia Democrata, Democracia, América Ilustrada e Opinião. ${ }^{58}$ A diretoria do Gabinete Português de Leitura convidou o presidente da província para presidir a sessão.

Durante as festividades do tricentenário, vários discursos foram pronunciados por diversos intelectuais: Clóvis Beviláqua, que na época era terceiroanista da Faculdade de do Recife; Pedro Celso Uchoa Cavalcanti, que falou pelos alunos do primeiro ano do curso de Direito; Carlos Porto-Carreiro, que discursou pela Escola Politécnica; Martins Júnior, o qual recitou o poema Duas épocas dedicado à "imorredoura memória de Luiz de Camões". Naquela ocasião, o cearense Beviláqua disse: "Então, ó Camões, quando alcançastes as praias da Índia, soerguendo os lusíadas, alcançastes ao mesmo tempo, as praias do futuro soerguendo a glória interior da tua nação".59

Esse evento ocorreu simultaneamente em Pernambuco, Rio de Janeiro, Bahia, Maranhão e Portugal. De Lisboa, a comissão do centenário enviou um

\footnotetext{
${ }^{58}$ Centenário de Camões, 5/jun/1880, p. 7 e 8.

${ }^{59}$ Apud AREIAS, Laura \& NOGUEIRA, Lucila, op. cit., p. 70.
} 
telegrama aos portugueses residentes em Pernambuco, congratulando o Gabinete Português de Leitura pela fraternal unanimidade e pela glorificação a Camões símbolo da nação portuguesa. O orador do gabinete no evento foi Veríssimo Ferreira Chaves Júnior e a festividade se estendeu até a meia noite. Ao final, foi executada a polka Jau, escrita pelo amador Francisco Gomes e ofertada ao gabinete. ${ }^{60}$

Apesar de tudo ter ocorrido conforme o planejado, nem toda a colônia portuguesa residente em Pernambuco contribuiu para a realização da comemoração. Todavia, o desânimo oriundo da falta de empenho de uma parte mais importante da colônia portuguesa não tirou o brilho da festa, pois contou com a dedicação da diretoria que com empenho fez acontecer o programado. ${ }^{61}$

Em relatório, a diretoria do gabinete português narrou que, a partir dessa comemoração, uma nova fase foi iniciada nos "fastos do humanitarismo". Podemos compreender essa afirmação como sendo um sinal do novo encaminhamento que a instituição passou a gerir. Em sua gênese, o gabinete evocou com mais frequência o discurso da irmandade, evidenciando que, apesar de diferentes, portugueses e brasileiros possuíam uma mesma filiação. E, no momento de sua criação, os lusitanos também se preocuparam em (re)construir um discurso que (re)significasse uma identidade deslocada da velha imagem de colonizador/explorador. A partir da adoção da homenagem a Camões, o GPL-PE passou (também) ${ }^{62}$ a destacar com maior intensidade a grandeza da gente e da pátria portuguesa a qual era uma herança dos grandes feitos tão bem propagados em Os lusíadas.

Nos discursos comemorativos, o Gabinete Português de Leitura ressurgiu como uma comunidade simbólica, uma espécie de extensão da pátria portuguesa em terras brasileiras. ${ }^{63}$ Nessa perspectiva, as tradições inventadas se apresentam no "conjunto de práticas (...), de natureza ritual ou simbólica, que buscam inculcar certos valores e normas de comportamentos através da repetição a qual automaticamente implica a continuidade do passado histórico adequado". ${ }^{64}$ Sendo assim, os discursos construídos em torno da

\footnotetext{
${ }^{60}$ Relatório, 10 de outubro de 1880, p. 4.

${ }^{61}$ Ibidem, p. 5.

${ }^{62}$ Também, pois o discurso da irmandade não desapareceu, mas a ênfase doravante se faz em Camões, o símbolo da nação portuguesa, que cantou sua glória. Logo, ser português era carregar consigo a herança civilizatória.

${ }^{63}$ HALL, Stuart, op. cit.

${ }^{64}$ HOBSBAWM, Eric E RANGER, Terence (org.). A invenção da tradição. Rio de Janeiro: Editora Paz e Terra, 2008, p. 1.
} 
mitificação de Camões também foram um dos pilares na (re)significação da identidade do imigrante português em Pernambuco. Ao evocar o passado, buscavam-se as glórias que engrandeciam o pertencimento à comunidade portuguesa, num claro reconhecimento da importância da utilização dos elementos antigos na preparação de novas tradições inventadas, sendo pertinente a posição de Hobsbawm e Ranger quando afirmam que "Sempre se pode encontrar no passado de qualquer sociedade um amplo repertório destes elementos; e sempre há uma linguagem elaborada, composta de práticas e comunicações simbólicas". ${ }^{65}$

No Brasil, os discursos em torno de Camões também apareceram atrelados ao termo "raça". Este termo passou a ser paulatinamente utilizado como uma evocação da "mais alta qualidade" da contribuição dos portugueses à formação da identidade nacional brasileira. Um trecho do documento produzido no tricentenário no Rio de Janeiro reforça que o discurso produzido em torno da (re)significação da identidade do imigrante português no Brasil considerava as conjunturas vividas.

A raça portuguesa possue em alto grau a faculdade de cosmopolitismo. Circumscripta em uma estreita facha da costa europea, experimenta a necessidade de espaço mais vasto, de mais larga esphera para exercer a sua actividade, provar as variadas aptidões de que é dotada.

Costumada a presenciar as fúrias do mar, com as quaes combate a miúdo, não lhes inspira medo a travessia do oceano e cruza-o em todas as direções. O seu genio aventureiro a conduz a todos os pontos do globo, e em qualquer latitude achareis vestígios da sua passagem, ou monumento da sua permanencia.

Tanto se habitua aos gelos polares como vive e se identifica na zona tórrida. É notavel a sua capacidade assimiladora, conservando todavia uma somma de qualidades ethnicas que lhes são de muito proveito na luta pela existencia.

O espirito de acquisição de propriedade domina grandemente cada um dos seus indivíduos, e em cada núcleo surge immediatamente a idea de associação, quer para fins beneficentes ou religiosos, quer para fins instructivos ou mero recreio.

Raro será da terra, em que, havendo residentes portuguezes, elles não tenham fundado sociedades de soccorros, confrarias religiosas, escolas, bibliothecas, philarmonicas e gymnasio. Na China e na Califórnia, na África como na America, achareis documentos

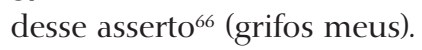

\footnotetext{
${ }^{65}$ Ibidem, p. 14

${ }^{66}$ Terceiro centenário de Camões, 1880, op. cit., p. 9.
} 
Essa menção ao termo "raça" aparece ligada à conjuntura que o Brasil vivenciava em torno da construção de uma identidade nacional em busca de um tipo ideal do homem brasileiro. O dr. Ferrer, sócio honorário do GPL-PE, ao discursar no aniversário da instituição em 15 de agosto de 1901, destacou a progressão do gabinete, apesar, disse ele, dos embaraços sofridos e "do desanimo tão commum a nossa raça". O termo "raça", como era comum naquele tempo, passou a ser usado com o definidor das características positivas e negativas do português pelos seus próprios conterrâneos em alguns momentos.

Em Portugal, foi somente a partir de 1924 que esse termo passou a ser atrelado à comemoração de "Camões". Os organizadores do centenário do nascimento de Camões (atribuído a 10 de junho de 1524) designaram a "Festa da raça", e nela o poeta foi identificado como o maior cantor da "raça". Esse termo, conforme fala Maria Isabel João, parecia reportar-se ao "conjunto do povo português, enquanto coletivo com um passado histórico comum, tradições e ideias que lhe conferem uma identidade própria". ${ }^{5}$ Em Pernambuco o termo "raça" esteve também presente na definição da arquitetura do prédio do GPL-PE.

\section{Uma arquitetura para a posteridade}

Era um sonho de muitos, desde a década de 1880, a construção de um prédio para o GPL-PE que traduzisse a grandeza da origem de seus associados.

No ano em que se comemorou o tricentenário de Camões, foi assentada a pedra fundamental do edifício do GPL-RJ; a construção do prédio concebeu uma arquitetura em que Portugal fosse exaltado e assim estimulasse os portugueses a ter a vaidade de pertencer à pátria portuguesa. Com o propósito da preservação da memória, a linguagem arquitetônica dos gabinetes teve a escultura como aliada, numa pontual e decisiva interação. ${ }^{67} \mathrm{O}$ estilo adotado, o neomanuelino, dava forma à memória e traduzia as intenções da instituição. Assim, a arquitetura aparecia para valorizar um passado grandioso, livrando-o do esquecimento. Ao se erguer um prédio para o Gabinete Português de Leitura, a arquitetura servia como resgate do passado de gló-

\footnotetext{
${ }^{67}$ MATTOS, Maria de Fátima da Silva Costa Garcia de. O neomanuelismo no Brasil: a identificação de um estilo através da sua instituição - os gabinetes portugueses de leitura. Tese de doutorado, Escola de Comunicação e Artes, USP, São Paulo, 2005, p. 144.
} 
rias, conquistas e feitos. E, apesar do passado colonial de exploração associado aos portugueses, tal arquitetura poderia contribuir para a (re)significação das identidades. Logo, a glória da pátria-mãe visualizada nessa arquitetura era também a glória de seus filhos.

Em 1901, a Poliantea commemorativa do cinquentenário de instalação da biblioteca do GPL-PE dizia que, assim como as demais associações portuguesas, os integrantes do mesmo conseguiriam erguer um prédio próprio. A construção fazia cumprir o propósito do artigo $1^{\circ}$ de seu estatuto ${ }^{68}$ que estabelecia metas ainda não alcançadas por causa da carência de recursos financeiros. Atribuía-se a escassez de meios ao número cada vez menor de associados bem como às muitas associações portuguesas. ${ }^{69}$ No relatório apresentado pela diretoria do gabinete em 1904, o tesoureiro da instituição apresentou o "Demonstrativo do caixa da comissão do prédio",70 mas foi em outubro de 1908 que se deu o assentamento da pedra fundamental e, passados quase treze anos, inaugurou-se o prédio em junho de 1921.

O prédio do GPL-PE não seguiu por completo o referencial arquitetônico dos demais edifícios das instituições portuguesas erguidas no Brasil. O modelo adotado pelos gabinetes do Rio de Janeiro e da Bahia seguiu o estilo neomanuelino, porém em Pernambuco a arquitetura baseou-se no ecletismo. Entretanto, devido a um incêndio ocorrido em 17 de julho de 1937, o prédio foi todo reformado, restando quase nada da construção original.

68 “O Gabinete Portuguez de Leitura (...) tem por fim promover o desenvolvimento intellectual e concorrer para o progresso moral dos seus associados, diffundindo por elles os conhecimentos uteis, por meio de conferencias, sessões litterarias e scientíficas, estabelecendo aulas nocturnas, sustentando uma bibliotheca escolhida e empregando quaesquer outros meios adequados e efficazes". Revista do 50 Aniversário da Instalação do Gabinete Portuguez de Leitura Pernambuco, número especial, 15 de agosto de 1901, p. 3.

${ }^{69}$ À comunidade portuguesa faltavam os meios de sustentar um grande número de associações. Para solucionar a escassez, Sousa Pinto sugeriu a fusão de todas a associações portuguesas, as quais resultariam num novo grêmio (Sociedade Portugueza de Litteratura, Instrucção e Beneficencia em Pernambuco) que cuidaria em respeitar o cumprimento dos deveres peculiares de cada grupo que existia. E deveria contemplar os principais dispositivos de todos os estatutos em vigor das associações que constituíssem a liga. Outro português, Carmo Luso, também defendeu a ideia de fusão das associações portuguesas, pois seria melhor uma única associação forte do que várias que nada faziam, segundo ele. Apesar de tais ideias não vingarem em sua totalidade, no início do século XX, ocorreu a incorporação da Associação Portuguesa de Beneficência em Pernambuco, logo após a fusão desta com a Sociedade Beneficente Monte Pio Português, ao Hospital Português de Beneficência. Desapareceram algumas outras instituições, mas surgiu também o Clube Português em 1927 (Gabinete Português de Leitura. Revista do 50 Aniversário da Instalação do Gabinete Portuguez de Leitura Pernambuco, op. cit., p. I, II, III).

${ }^{70}$ Relatório do Gabinete Portuguez de Leitura em Pernambuco, 1905, p. 13. 
Contudo, em sua recuperação, não foi esquecida a referência ao estilo manuelino.

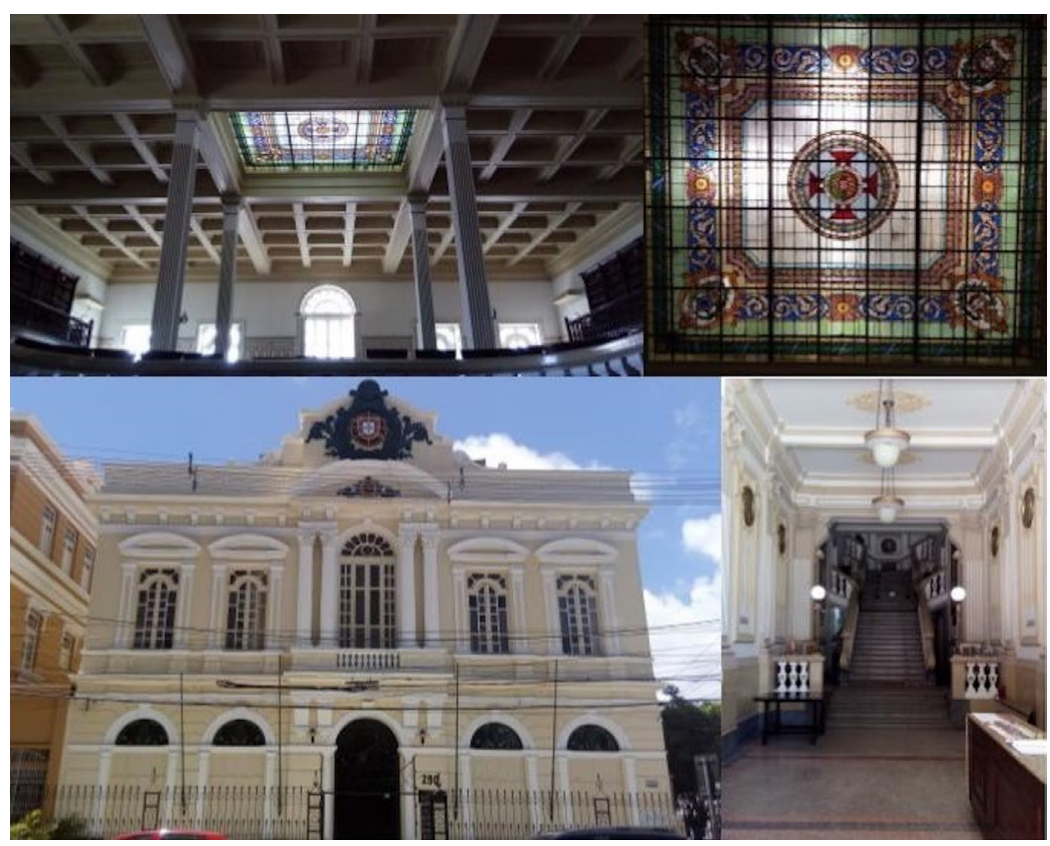

Salão nobre com destaque à grandiosidade proporcionada pelo pé-direito e colunas esbeltas, e vitral ao centro com o emblema da Ordem de Cristo: a cruz, uma simbologia manuelina; fachada do edifício em estilo neoclássico e hall de entrada com recepção/escada ao fundo.

Fonte: Laura Cândida dos Santos.

O relatório sobre a inauguração do prédio do GPL-PE ressaltava que a concretização da construção do prédio tornara real o desejo de se construir um prédio símbolo da "raça lusa", almejado desde a década de 1880. Situado no bairro de Santo Antônio, o prédio compunha o complexo da cidade visto como local mais "civilizado" - perto do teatro Santa Isabel e da sede do governo. $\mathrm{O}$ "majestoso prédio" materializava a importância da instituição à comunidade portuguesa residente no Estado e representava uma extensão da "pátria portuguesa" em terras pernambucanas. ${ }^{71}$

Um relato feito sobre o prédio do gabinete do Rio de Janeiro e que se adequa à história do Gabinete Português de Leitura de Pernambuco é

${ }^{71}$ Iphan. Typografia Minerva Central de J. A. Carvalho. África Oriental Portuguesa, 1923. 
apropriado para a finalização deste artigo. Ao ser objeto de discurso, aquele gabinete foi traduzido como um monumento histórico, considerando-se que, mesmo se fossem destruídos os arquivos portugueses e brasileiros, "não deixando memória escrita do amor fraternal dos dois povos, aquele esplêndido monumento erguido por portugueses no Brasil diria às gerações futuras que, unidos como estão, ali o solo e a obra d'arte (...)" funcionaria como memória do povo lusitano em terras brasileiras.

Nesse sentido, o prédio erguido materializava as ideias expressas nos discursos que ora se ampararam na definição das fronteiras identitárias do imigrante português, ora se apoiaram no poeta Camões, o herói da nação portuguesa e símbolo do emigrante português. Assim, a memória da nação portuguesa passou a ser evocada por aquilo que era tido como merecedor de ser registrado e não somente por mera preservação do passado. O prédio do Gabinete Português de Leitura de Pernambuco assumiu, dessa forma, a função de monumento histórico, o qual, conforme Jacques Le Goff, é “o resultado do esforço das sociedades históricas para impor ao futuro, voluntária ou involuntariamente, determinada imagem de si próprias". ${ }^{72}$ Logo, compreender a história desta instituição nos possibilitou entender como os portugueses pensaram a si próprios e (re)construíram os discursos que (re) significaram sua identidade em Pernambuco.

\section{Conclusão}

Ao se escolher o Gabinete Português de Leitura de Pernambuco como referencial de análise, considerou-se que as vivências dos seus sócios foram representativas apenas de uma parte dessa comunidade. Porquanto, ao se pensar a história da comunidade portuguesa e se considerar a visão do próprio português sobre os acontecimentos que lhes afetaram no período pós-independência, desembocou-se numa visão que se diferenciou das outras histórias contadas sobre esta comunidade em Pernambuco. Ao se observar que uma experiência adquire significados diversos a partir das várias interpretações que cada personagem consegue transmitir de uma mesma situação, aludimos à interpretação de Clifford Geertz, o qual pondera que o exame da construção/desconstrução da realidade social deve observar as várias percepções dos grupos sociais para que se compreenda como os

\footnotetext{
${ }^{72}$ LE GOFF, Jacques. Documento/Monumento. In: Enciclopédia Einaud. Lisboa: Imprensa Nacional: Casa da Moeda, 1984, p. 103.
} 
agentes sociais representam a si mesmos e o mundo que os cerca. ${ }^{73}$ É válido registrar que as respostas encontradas com base nos integrantes do Gabinete Português de Leitura não foram nem devem ser tomadas como modelo absoluto e representativo de toda a comunidade portuguesa, mesmo porque os homens são livres para vivenciar suas experiências a partir daquilo que se torna mais importante para eles mesmos.

Daí conclui-se que o GPL-PE foi ator e, ao mesmo tempo, palco em/ de vários cenários. Surgiu num contexto de extrema lusofobia, como um ator que visava mudar a cena das acusações sofridas por aqueles a quem representava naquele momento; era uma espécie de subterfúgio para os portugueses residentes na província pernambucana e buscava se instalar/ apresentar como palco de um novo cenário. Naquele palco, os portugueses eram apresentados pelos benefícios que traziam e pretendiam oferecer aos pernambucanos. A necessidade de (re)significar a identidade estereotipada do imigrante português e sua relação com o passado colonial foi a cena mais trabalhada neste e por este ator, o qual teve muitos representantes. Um destes, o sócio fundador João Vicente Martins não fez eufemismos ao apresentar a instituição como uma "árvore frondosa" que dava somente bons frutos (frutos esses representados pelos seus sócios portugueses). E, apesar de ser alvo de debates e rebates, impôs-se como a principal (além de ser a primeira) associação portuguesa após a independência do Brasil no norte agrário da nova nação. Foi em seu seio que surgiram as demais associações portuguesas que floresceram na província pernambucana: o Hospital Português, em 1855; a Associação Beneficente Monte Pio Português, em 1864; a Associação Beneficente Portuguesa, em 8 de dezembro de 1872, que inicialmente foi denominada Associação Portugueza de Beneficencia dos Empregados no Comércio e Indústria de Pernambuco; e o Grêmio Caixeiral Thomaz Ribeiro. O Hospital Português, por exemplo, funcionou provisoriamente no salão do GPL-PE. ${ }^{74}$

O percurso traçado pelos integrantes do gabinete acompanhou as conjunturas da nação brasileira e se adequou às necessidades que se impuseram dia a dia. A instituição concentrou seus discursos na negociação identitária, buscando delimitar as fronteiras entre ser português e ser brasileiro, sem com

\footnotetext{
73 GEERTZ, Clifford. A interpretação das culturas. Rio de Janeiro: LTC, 1989, p. 21.

${ }^{74}$ APEJE. Comissões diversas, DII, 14/09/1855, fl. 128. O Hospital Português teve seus primeiros atendimentos numa sala do GPL-PE e somente em 2 de novembro de 1855 passou a funcionar em prédio próprio (APEJE. Diversos II, 22/11/1855, fls. 132, 135).
} 
isso buscar o isolamento cultural - até porque o português e o brasileiro possuíam semelhanças inquestionáveis. Contudo, um e outro eram diferentes.

Devido à forte lusofobia, a negociação identitária foi prioridade no primeiro momento da concepção deste gabinete. Porém, a partir da década de 1880, com a comemoração do tricentenário de Camões, a ideia de "nação portuguesa" foi ganhando mais espaço e o Gabinete Português de Leitura assumia, nos discursos produzidos em torno de si, o caráter simbólico de extensão da pátria portuguesa. E para que essa representação fosse absoluta, vislumbrou-se a construção de um prédio que representasse os portugueses com a honra e esplendor sonhados pelos seus sócios, materializando, assim, a ideia de grandeza da nação e da "raça portuguesa" num monumento à posteridade.

Percebe-se que a construção do prédio fechou o ciclo em torno da formalização de uma identidade que nele se materializava. Não obstante, este estudo sobre a (re)construção dos discursos em torno da (re)significação da identidade do imigrante português em Pernambuco merece maior atenção, pois ainda há muitas histórias a serem compreendidas em seus percursos.

\section{Referências bibliográficas Fontes consultadas}

Almanach de Pernambuco, jul./1916.

Estatuto do Gabinete Português de Leitura. Recife: Typografia Universal, 1855.

Estatuto do Gabinete Português de Leitura em Pernambuco, 1862. Recife: Typ. Commercial de G. H. de Mira. Rua Estreita do Rosário, n. 12.

Fastos do Gabinete Portuguêz de Leitura em Pernambuco. Coleção de poesias e discursos recitados na sessão magna do décimo-oitavo anniversario da abertura em 31 de outubro de 1869. Recife: Typographia do Correio do Recife, 1970. Iphan, Typografia Minerva Central, de J. A. Carvalho. África Oriental Portuguesa, 1923. Polyantea comemorativa dos cinquenta anos do Gabinete Português de Leitura de Pernambuco, 1901.

Relatório de 10/10/1880, relatando as ações da diretoria no período de $1^{\circ}$ de outubro de 1879 a 30 de setembro de 1880 e Polyanthea comemorativa.

Relatório da diretoria do Gabinete Português de Leitura de Pernambuco. Recife, 18/nov./1880.

Relatório apresentado a assembleia geral do Gabinete Português de Leitura em Pernambuco, pela diretoria do mesmo em outubro de 1880. Typ. de Manoel Figueroa e Faria $\mathcal{E}$ Filhos, 1880.

Relatório do Gabinete Portuguez de Leitura em Pernambuco, 1904-1905. Recife: Imprensa Industrial, 1905.

Revista O Gabinete Portuguez de Leitura em Pernambuco - 1850, número especial, 3 de novembro de 1900. Recife: Imprensa Industrial Nery da Fonseca $\mathcal{E}$ Com. 
Revista do 50 Aniversário da Instalação do Gabinete Portuguez de Leitura Pernambuco, número especial, 15 de agosto de 1901.

Terceiro centenário de Camões. Juízo da Imprensa do Rio de Janeiro acerca do relatório da diretoria do Gabinete Português de Leitura em 1880. Rio de Janeiro, 1880.

\section{Jornais e periódicos}

Diário de Pernambuco, 1850, 1852, 1854, 1880, 1882, 1921.

O Médico do Povo, Rio de Janeiro, 1850.

O Século, 1851, Pernambuco.

\section{Bibliografia}

ALVES, Jorge Fernandes. Os brasileiros: emigração e retorno no Porto oitocentista. Porto: 1994. Variações sobre o "brasileiro" - Tensões na emigração e no retorno do Brasil. Revista Portuguesa de História, tomo XXXIII, 1999, U. Coimbra, p. 191-222.

ARARIPE, Fátima Maria Alencar. Do patrimônio cultural e seus significados. Campinas: Transinformação [online] , vol. 16, n. 2, 2004, p. 111-122. ISSN 2318-0889. Disponível em: http://www.brapci.inf.br/v/a/20447. Acesso em: 2006. DOI: http://dx.doi.org/10.1590/S0103-37862004000200001.

AREIAS, Laura $\mathcal{E}$ NOGUEIRA, Lucila.Monografia do GabinetePortuguês de Leitura. Recife, 2000.

AUGÉ, Marc. Não lugares: introdução a uma sociologia da supermodernidade. Campinas: Papirus, 1994.

BASTOS, Tatiana Quintela de Azeredo. Gabinete Português de Leitura: construção de uma identidade portuguesa (1837-1893). Dissertação, UFRJ, 2007.

CÂMARA, Bruno Augusto Dornelas. Trabalho livre no Brasil imperial: o caso dos caixeiros de comércio na época da Insurreição Praieira. Dissertação de mestrado, CFCH, UFPE, 2005.

CARVALHO, Marcus Joaquim Maciel de. O antilusitanismo e a questão social em Pernambuco, 1822-1848. In: PEREIRA, Miriam Halpern (org.). COLÓQUIO INTERNACIONAL SOBRE EMIGRAÇÃO E IMIGRAÇÂO EM PORTUGAL (SÉC. XIX E XX). Actas. Lisboa, Portugal: Editora Fragmentos, 1993, p. 145-162.

CAVALCANTI, Paulo. Eça de Queiroz: agitador no Brasil. Recife: Editora Guararapes, 1983.

CUCHE, Denys. A noção de cultura nas ciências sociais. Bauru: Edusc, 1999.

DIELH, Astor Antônio. Cultura historiográfica: memória, identidade e representação. Bauru, SP: Edusc, 2002.

FERRÃO, Luiz Felipe Vieira. Instituto Arqueológico Geográfico Pernambucano: um tributo a memória regional (1848-1911). Dissertação, PPGH, UERJ, 2001.

FERRAZ, Luiz Paulo Pontes. "Deus te leve a Pernambuco": antilusitanismo, legislação e estatística na história da imigração portuguesa para Pernambuco (1945 - 1964). Dissertação de mestrado, CFCH, UFPE, 2014.

FREYRE, Gilberto. Nordeste. Rio de Janeiro: Editora Record, 1989.

GEERTZ, Clifford. A interpretação das culturas. Rio de Janeiro: LTC, 1989.

HALL, Stuart. Identidade cultural na pós-modernidade. Rio de Janeiro: DPËA, 2000.

HOBSBAWM, Eric $\mathcal{E}$ RANGER, Terence (org.). A invenção da tradição. Rio de Janeiro: 
Editora Paz e Terra, 2008.

HOFFNAGEL, Marc Jay. Rumos do republicanismo em Pernambuco. In. SILVA, Leonardo Dantas (org.). A República em Pernambuco. Recife: Fundaj, Ed. Massangana, 1990, p. 158- 179.

JOÃO, Maria Isabel. Memória e Império: comemorações em Portugal (1880-1960). Lisboa: Fundação Calouste Gulbenkian, 2002.

LE GOFF, Jacques. Documento/Monumento. In: Enciclopédia Einaud. Lisboa: Imprensa Nacional; Casa da Moeda, 1984.

LESSER, Jeffrey. A negociação da identidade nacional: imigrantes, minorias e a luta pela etnicidade no Brasil. São Paulo: Unesp, 2001.

LOURENÇO, Eduardo. Mitologia da saudade: seguido de Portugal como destino. São Paulo: Companhia das Letras, 1999.

MATTOS, Maria de Fátima da Silva Costa Garcia de. O neomanuelismo no Brasil: a identificação de um estilo através da sua instituição - os gabinetes portugueses de leitura. Tese de doutorado, Escola de Comunicação e Artes, USP, São Paulo, 2005.

MELLO, Evaldo de Cabral. O norte agrário e o Império, 1871 -1889. Rio de Janeiro: Nova Fronteira; Brasileira; INL, 1984.

Rubro veio: o imaginário da restauração pernambucana. Rio de Janeiro: Topbooks, 1997.

OLIVEIRA, Roberto Cardoso. Caminhos da identidade: ensaios sobre etnicidade e multiculturalismo. São Paulo: Editora Unesp, 2000.

POUTGNAT, Philippe \& STREIFF-FENARTE, Jocyline. Teorias da etnicidade. Seguido de grupos étnicos e suas fronteiras de Fredrik Barth. São Paulo: Editora da Unesp, 1998.

RIBEIRO, Mário Antônio Cabral. História da homeopatia no Brasil, 2008. Disponível em: http: //amhb.org.br/media/docs/Historia\%20da\%20Homeopatia \%20 no\%20 Brasil_geral.pdf.

SANTOS, Wilza Betania dos. A (re)significação duma identidade portuguesa: o Gabinete Português de Leitura de Pernambuco e o seu contexto político e social (1850-1921). Dissertação de mestrado, História Contemporânea, Faculdade de Letras da Universidade do Porto, Flup, 2013.

Gabinete Português de Leitura de Pernambuco: uma análise sua criação em meio ao contexto lusófobo do século XIX. Monografia, curso de Especialização em Ensino de História, Recife, UFRPE, 2007.

SCHWARCZ, Lilia Moritz. O espetáculo das raças: cientista, instituições e questão racial no Brasil - 1870-1930. São Paulo: Companhia das Letras, 1993.

TAVARES, Antônio Rodrigues. Fundamentos e actualidades do Real Gabinete Português de Leitura. Edição comemorativa do $140^{\circ}$ aniversário de fundação. Rio de Janeiro: Publicação do Real Gabinete Português de Leitura do Rio de Janeiro. 